\title{
Four-years of monitoring a breeding colony of black-necked stilt (Himantopus mexicanus) on the Rio Grande do Norte State coast, Brazil
}

\author{
M. L. A. Mendonça $a^{a}$, A. P. R. Elias ${ }^{a}$, D. G. Lunardi ${ }^{b}$ and V. O. Lunardi ${ }^{a, b *}$ \\ aPrograma de Pós-graduação em Ecologia e Conservação, Universidade Federal Rural do Semiárido - UFERSA, \\ Av. Francisco Mota, 572, CEP 59625-900, Mossoró, RN, Brasil
}

bPrograma de Pós-graduação em Ambiente, Tecnologia e Sociedade, Universidade Federal Rural do Semiárido - UFERSA, Av. Francisco Mota, 572, CEP 59625-900, Mossoró, RN, Brasil

*e-mail: lunardi.vitor@ufersa.edu.br

Received: May 5, 2017 - Accepted: August 30, 2017 - Distributed: February 2, 2019

(With 2 figures)

The black-necked stilt (Himantopus mexicanus Statius Müller, 1776) is the widest distributed Recurvirostridae species of the Americas, with resident and wintering populations in many wetlands. Researches on behavior, population ecology and threats of this shorebird species have focused on Northern Hemisphere populations, and comparatively little about these topics is known of its southernmost populations (Robinson et al., 1999). In 2013, we registered and described the first breeding colony of black-necked stilt in northeastern Brazil, in a non-natural saline area of the Apodi-Mossoró River Estuary (AMRE), Rio Grande do Norte State (Lunardi et al., 2015). In the current study, we presented data of a four-years (2012-2016) of monitoring the site used as breeding colony to provide additional information regarding seasonality and breeding success of the species in the northeastern Brazil.

The study site comprised an artificial saline area (145 ha) located at the mouth of the AMRE (04⒌' S, $\left.37^{\circ} 08^{\prime} \mathrm{W}\right)$, Rio Grande do Norte State, Brazil. The study site consists of 54 continuous saline ponds (1-2 ha each) limited by small dikes (1-2 $\mathrm{m}$ wide) and two unpaved roads (5-7 m wide; used for salt transportation and not used by birds). The black-necked stilt reproductive colony occupied an area of $\sim 106$ ha in the study area (Lunardi et al., 2015).

Between August 2012 and July 2016, two researchers conducted two fortnightly counts (during high and low tide periods, in consecutive days) of black-necked stilts ( $n=192$ counts), in 54 fixed observation sites, located on the two unpaved roads and in front each one of the 54 ponds. In each count, the same two researchers walked $(\sim 3 \mathrm{~km} / \mathrm{h})$ between the fixed observation sites only on the unpaved roads to avoid disturbing black-necked stilts. The data obtained in the 54 fixed points were added up to each count and it was used as an estimate of the total number of black-necked stilts present in the study area. Two binoculars $\left(8 \times 40 \mathrm{~mm} /\right.$ Bushnell $\left.^{\circledR}\right)$ and a digital camera (DSC-H100/Sony ${ }^{\circledR}$ ) were used in the counts. Each count was conducted in $\sim 2 \mathrm{~h}$. Annual fluctuation in abundance between the studied years was analyzed with KruskalWallis nonparametric test $(H)$ and Dunn's post-tests were performed. In this study, each studied year corresponded to the period between July and August.

Two breeding seasons of black-necked stilts were monitored during the study: 2014 and 2015. Between
May and August of 2014 and 2015 years, we additionally conducted $\sim 3 \mathrm{~h}$ visits to the study area, in intervals of 2-3 days, to search for and monitor nests, eggs, and chicks in all the study area. The $\sim 3 \mathrm{~h}$ period was established because this was the average time of searching for nests, eggs and offspring (that are naturally inconspicuous) on all dikes. In 2014, 24 visits were carried out in the study area, and 28 visits in 2015 . Searches and monitoring were conducted by the same two researchers slowly walking on the two parallel-unpaved roads and dikes. Binoculars were used to locate and monitor nests/eggs/chicks on the dikes, and the average distance of nest observation on dikes was $\sim 10 \mathrm{~m}$. Eggs and nests were measured when adults were not close to the nest, in order to minimize nest abandonments and avoid attracting predators. During nest monitoring in each studied breeding season, we recorded the following data for each located nest: height between the nest and the pond's water level; outer and inner nest diameters; number of eggs and their dimensions; and, distance between the nest found and the nearest nest (details in Lunardi et al., 2015). Nest status was also recorded and classified into one of four categories during nest monitoring: under construction (absence of eggs, chicks, or traces of hatching or predation, and adults exhibiting nest construction behaviors); active (presence of at least one intact egg and no traces of hatching or predation); preyed (nests 'active' that were found a destruction of at least one egg or chick); successful (presence of at least one chick in the nest or near it); and, unsuccessful (nests 'under construction' that were abandoned during the breeding seasons). The data from the 2013 breeding season (Lunardi et al., 2015) were comparatively analyzed with the data of the present study. Data are given as means $\pm \mathrm{SE}$ follow by range.

The total number of black-necked stilts recorded in all the 192 counts from August 2012 to December 2016 was 6,083 (26.5 \pm 4.3 individuals/count). The species exhibited seasonal occurrence in abundance between 2012 and 2016, with presence recorded mainly between March and October (Figure 1). The abundance reduced markedly through the 4-year study period $(H=12.28$; $p=0.002$ ), but there was verified a significant difference in abundance only between 'August 2015 and July 2016 period' and the three others respective studied periods 


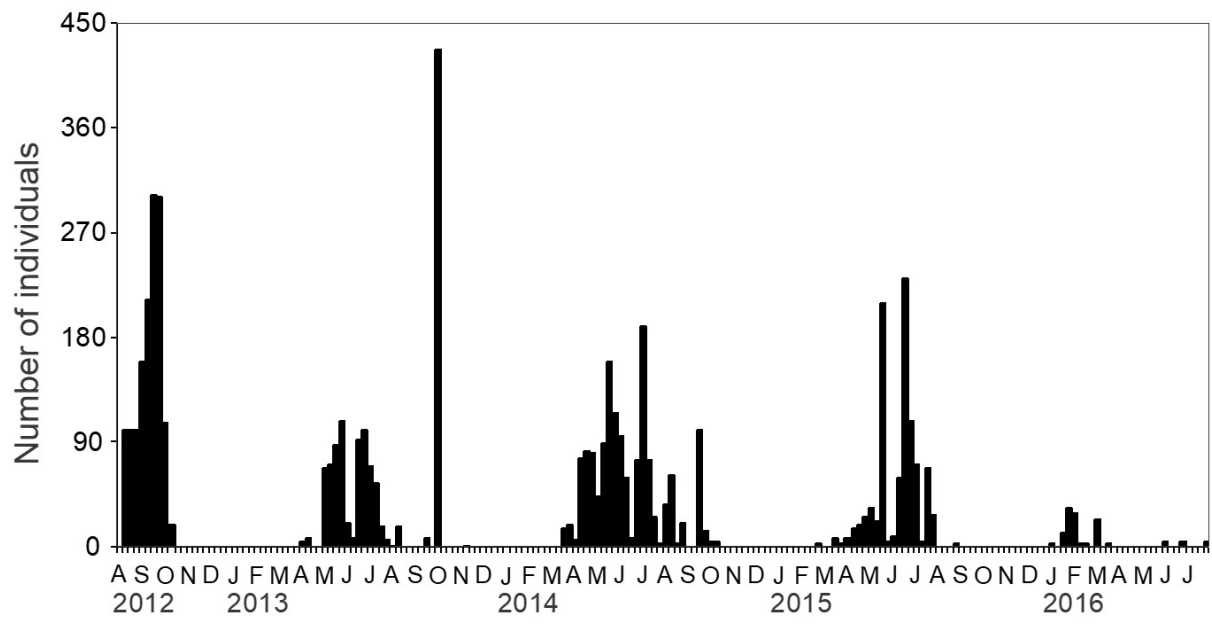

Figure 1. Number of recorded black-necked stilt individuals in a 145 ha artificial saline area at northeastern Brazil. The bars represent 192 counts between August 2012 and July 2016.

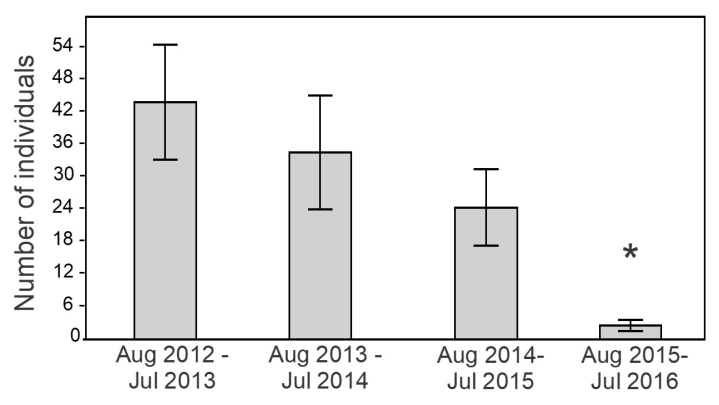

Figure 2. Annual fluctuation in black-necked stilt abundance in a 145 ha artificial saline area at northeastern Brazil. Bars are means (error bars are standard errors) from 48 individuals counts data from each 'July to August' studied periods. Asterisk indicates the period that presented significant difference in individuals/count $(p<0.01)$ by Dunn's post-tests.

(Figure 2). The high rate of nest predation (see below) can be an explanation for this reduction.

The breeding seasons occurred between May and August. The recorded nests were placed especially at $51-100 \mathrm{~cm}$ above water level $(93.5 \%$ of the nests). All the nests were in the dry ground on the dikes of the evaporation ponds, easily accessible by land. None nests found had been drowned by the increase in water level of the ponds. The average distance between nearest pairs of nests in the breeding colony; the nests and eggs sizes; the total numbers of nests found; active nests in the exact moment that these nests were found; preyed nests; and the successful nests in the end of the breeding seasons are presented in Table 1. Domestic dog footprints were found near some preyed nests.

The black-necked stilt is considered a year-round resident in the Southern Hemisphere (review in Robinson et al.,
1999). The seasonal occurrence pattern of this shorebird species in the studied area indicated that the species use the salines of AMRE especially as a breeding site between March and October, and travels to post-breeding locations between November and January. In fact, during the breeding periods of the 2014, 2015, and 2016 years, we observed black-necked stilts displaying reproductive behaviors in several others saline sites within the AMRE. And, in the post-breeding periods, we frequently found black-necked stilt groups foraging in remnant natural lagoons and in artificial ponds made for human and agriculture in the AMER. Possibly, the species has multiple centres of activity within the AMRE and surroundings, as observed in the San Francisco Bay estuary (Hickey et al., 2007).

The breeding periods, clutch sizes, eggs and nests length of the black-necked stilts in the saline area of AMRE resembles those described for populations of this species in other regions of its distribution (see Robinson et al., 1999; Larrazábal et al., 2002; Ackerman et al., 2014). In spite of these resembles, we registered high rates of nest predation at the study area. The use of dry areas on the dikes of evaporation ponds to nest (ease to terrestrial predators reach by land), and the constant presence of domestic dog (from houses located adjacent to the saline; personal obs.), might be some of the factors that caused high rates of nest predation. The consecutives high nest predation rates in the studied breeding periods may be the factor that explains the tendency of reduction in the abundance of individuals and nests in the studied site.

These results confirm the region of the AMRE as an annual breeding ground of the black-necked stilt in the Southern Hemisphere, and suggest low breeding success in the salines and the use of multiple use areas within this estuary in respect of the breeding and non-breeding periods. Governmental agencies and the administrators of the salines should use theses finds to build a collaborative action plan for the black-necked stilt conservation in salines of the northeastern Brazil. A first management action should 
Mendonça, M.L.A. et al.

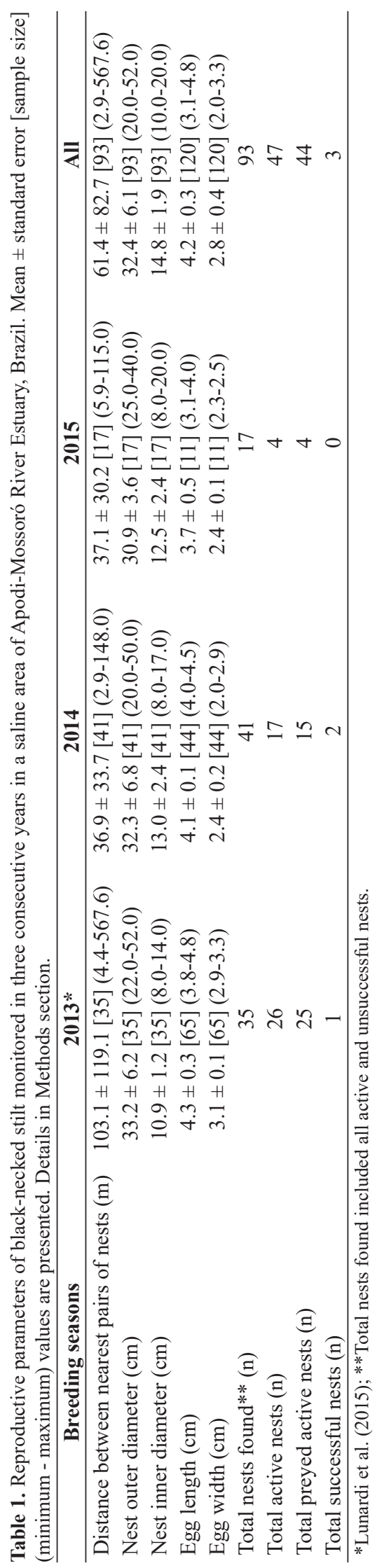


be the fencing of the dykes with electric fences to avoid the entry of domestic dogs (e.g. Ivan and Murphy, 2005).

\section{Acknowledgements}

CIASAL-Indústria Salineira Ltda. for permission to conduct the study. Fundação de Apoio à Pesquisa do Estado do Rio Grande do Norte/FAPERN and Conselho Nacional de Desenvolvimento Científico e Tecnológico/CNPq for financial support (Grant n. 005/2011/PPPIV). Coordenação de Aperfeiçoamento de Pessoal de Nível Superior-CAPES for the master fellowship to A.P.R. Elias. We are grateful for Dr. Lilian T. Manica and two anonymous reviewers for previous insightful suggestions for the manuscript.

\section{References}

ACKERMAN, J.T., HERZOG, M.P., TAKEKAWA, J.Y. and HARTMAN, C.A., 2014. Comparative reproductive biology of sympatric species: nest and chick survival of American avocets and black-necked stilts. Journal of Avian Biology, vol. 45, no. 6, pp. 609-623. http://dx.doi.org/10.1111/jav.00385.
HICKEY, C., WARNOCK, N., TAKEKAWA, J.Y. and ATHEARN, N.D., 2007. Space use by black-necked stilts Himantopus mexicanus in the San Francisco Bay estuary. Ardea, vol. 95, no. 2, pp. 275288. http://dx.doi.org/10.5253/078.095.0210.

IVAN, J.S. and MURPHY, R.K., 2005. What preys on piping plover eggs and chicks? Wildlife Society Bulletin, vol. 33, no. 1, pp. 113-119. http://dx.doi.org/10.2193/0091-7648(2005)33[113:WP OPPE]2.0.CO;2.

LARRAZÁBAL, M.E., AZEVEDO-JÚNIOR, S.M. and PENA, O., 2002. Monitoramento de aves limícolas na Salina Diamante Branco, Galinhos, Rio Grande do Norte, Brasil. Revista Brasileira de Zoologia, vol. 19, no. 4, pp. 1081-1089. http://dx.doi.org/10.1590/ S0101-81752002000400013.

LUNARDI, V.O., MENDONÇA, M.L.A., ELIAS, A.P.R. and LUNARDI, D.G., 2015. First record of a breeding colony of black-necked stilt Himantopus mexicanus (Aves: Recurvirostridae) in northeastern Brazil. Brazilian Journal of Biology $=$ Revista Brasileira de Biologia, vol. 75, no. 4, suppl. 1, pp. 259-261. http://dx.doi.org/10.1590/1519-6984.24014. PMid:26602343.

ROBINSON, J.A., REED, J.M., SKORUPA, J.P. and ORING, L.W., 1999 [viewed 18 November 2014]. Black-necked stilt (Himantopus mexicanus). In: A. POOLE, ed. The birds of North America [online]. Ithaca: Cornell Laboratory of Ornithology. Available from: http://bna.birds.cornell.edu/bna/species/449. 